\title{
The Influence of Motivation On Quality Service Delivery in Decentralised Indonesia
}

\author{
EDDY S. SOEGOTO \\ Faculty of Economic and Business, Universitas Komputer Indonesia, Bandung 40132, Indonesia \\ Email correspondence: eddysoeryanto@unikom.ac.id
}

\begin{abstract}
In this study, the authors sought to examine the relationship between motivation and quality service delivery in a decentralised Indonesia. In an effort to have fair findings, a sample of the study was obtained from 102 local government service delivery recipients. The selected samples included department heads whose sectors became units of inquiry and analysis. During the data collection process, questionnaires were used and data analysis entailed running correlations and regressing motivation practices on quality service delivery. The results have shown that motivational practices positively and significantly predict quality service delivery in a decentralised Indonesia. Besides, the results also revealed that motivation positively and significantly influences quality service delivery in districts found in the West Java Province, especially, Bandung city.
\end{abstract}

Key words: Service Delivery, Motivation, Managing Motivation, and Decentralised Indonesia.

\section{Pengaruh Motivasi Terhadap Pemberian Qualitas Pelayanan Desentralisasi di Indonesia}

\begin{abstract}
Abstrak
Dalam penelitian ini, penulis berusaha untuk meneliti hubungan antara motivasi dan kualitas pelayanan desentralisasi di Indonesia. Dalam upaya untuk mendapatkan temuan yang adil, sampel penelitian diperoleh dari 102 penerima layanan pemerintah daerah. Sampel yang dipilih termasuk kepala departemen yang sektornya menjadi unit penyelidikan dan analisis. Selama proses pengumpulan data, kuesioner digunakan dan analisis data melibatkan korelasi yang berjalan dan praktik motivasi yang menurun terhadap pemberian layanan berkualitas. Hasilnya menunjukkan bahwa praktik motivasi secara positif dan signifikan memprediksi pemberian layanan berkualitas di Indonesia yang terdesentralisasi. Selain itu, hasil penelitian juga menunjukkan bahwa motivasi berpengaruh positif dan signifikan terhadap kualitas pelayanan di kabupaten yang terdapat di Provinsi Jawa Barat, khususnya Kota Bandung.
\end{abstract}

Kata kunci: Pemberian Layanan, Motivation, Mengelola Motivasi, Desentralisasi Indonesia. 


\section{INTRODUCTION}

Motivation is an important factor for individuals or companies' success. Because it is a psychological aspect which drives a living organism to act in a desired direction. It is a theoretical construct which helps to explain how living organisms behave (Schneider and Alderfer, 1973), hence representing the reasons behind the different actions, interests and attitudes of people or living creatures.

Motivation is a primary cause of behaviour (Cofer and Appley, 1964) and other psychological aspects. According to Barnet and Simmering (cited on 4th August, 2017) basing on Sigmund Freud's argument, they also affirmatively suggest that the most powerful determinants of individual behaviour are the hidden traits which individuals are not consciously awareof. Though there might be other possible reasons regarding the difference in individual motivations (Steers, Lyman and Gregory, 1996) internal drive remains the most outstanding factor that compels motivation in most people.

Motivation may influence service delivery due to the fact that employees who are empowered and motivated within an organisation tend to either express a positive or negative image to the customers (Amaanda, 2011). Employees can portray positive and negative attitude through dignity and autonomy which are reflected in Maslow's work on Hierarchy of needs (Hadi, Wahyudin, Ardiwinata and Abdu, 2015). Wamaungo (2011) points out that these needs can be achieved through education which is a component to proper service delivery.

In this research, the authors aimed to examine the relationship between motivation and quality service delivery in a decentralised Indonesia. Because there are many theories which been explored to explain motivation as a driving force to actions, These theories include that of Maslow's hierarchy of needs and Herzberg. However, though there are many theories, Maslow's theory is the commonly used theory. According to Maslow (1954) man inhabits inner potentials which keep growing and it is these inner potentials which drive an individual to aim at achieving life objectives. For simplicity purposes, Maslow developed a hierarchy of needs which has been used in several situations to describe or classify human motives (Wahba and House, 1974).

Herzberg proposes two theories which describe workplace situations leading to employee satisfaction and that if they are not followed, it can lead to working dissatisfaction. In his book titled 'The Motivation to Work', written with his colleagues, Herzberg and colleagues examined thirty years of motivational research in job-related areas and their findings are said to have stimulated research and controversy that continue until now (Herzberg, Mausner and Snyderman, 2011).

Herzberg and colleague further mention that there are several factors that motivate individuals and organisations, hence making most individuals change over time, however, the most important aspect is motivation which exists at almost every level (Burton, 2012). Motivation energizes each and every individual in the company. It makes employees feel they are part and partial to an organisation's struggle.

Indonesia has been decentralised since independence, however, it is more applicable today than ever. This research was conducted in Bandung city as the capital city of the West Java Provinces to examine the influence of motivation on a decentralised Indonesia. The demand for services in decentralization are more likely to be reflected by the decisions and public opinion about expenditures on government services.

\section{Research Problem}

Though decentralization is about the transfer of power and assignment of accountability and responsibility for better services (Business dictionary, accessed on 4th August, 2017)from a central system to a localised system. It comes many tasks which include delegation of functions from a senior officials to more junior officials. In such as situation, there is need for energizing the working team at all levels, this can be done through motivation.

The vision of West Java Province in Indonesia is becoming 'Advanced and Prosperous' there are several mechanisms which have been put in place to ensure advancement and prosperity for all. This provincial vision is in line with that of the districts, especially Bandung city whose vision is to be a service city that is clean, prosperous, abides to the rule of law 
JURNAL BISNIS \& MANAJEMEN

ISSN 1412 - 3681

and hospitable to each and every person.

In this regard, motivation is a fundamental component, among the many factors required to achieve the said visions of both Bandung and the Province at large. The motivation process has to reach each and every department if services are to be satisfactorily delivered to the public.

Given this role, most local governments in a decentralised Indonesia are deliberately making efforts to improve and fulfil all the required deliverable inputs. However, despite such efforts, the quality of services delivered is still questioned. This is mainly reflected in the city's budget performance. The present situation suggests that some how there limited or poor quality service delivery, hence calling for an empirical review.

\section{Hypotheses of The Study}

Hypothesis (1)

$\mathrm{H} 1$ : A There is significant relationship between motivation and quality service delivery in a decentralised Indonesia.

Hypothesis (2)

$\mathrm{H} 2$ : A Motivation does not significantly affect quality service delivery in a decentralised Indonesia.

H3 : A Motivation significantly affects quality service delivery in a decentralised Indonesia.

This study is of benefit to Indonesia because it aims at improving the employee's working conditions within Indonesia's decentralised system who are to benefit from motivation, such as motivational training. The study is also useful to researchers interested in almost a similar problem. In this regard, the present study may provide useful information to all stakeholders with the realm of power.

\section{LITERATURE REVIEW}

There are different forms of motivation and among such forms is the Intrinsic and extrinsic forms of motivation. Knowledge of the different forms of motivation helps employers to provide appropriate treatment and enables them to organize and reorganize in an effective manner. According to the Sansone and Harackiewicz (2000) intrinsic motivation is the outstanding form which reflects the natural human capacity to learn and retain information. While, the extrinsic motivation varies depending on the situation, hence commonly influencing individual self.

\section{The Intrinsic Type of Motivation}

Intrinsic motivation is defined differently however, Ryan and Deci (2000) refer to it as the doing of an activity for its inherent satisfactions rather than for some separable consequence. They have argue that an individual is intrinsically motivated, he or she is moved to act for the fun or challenge entailed rather than because of external prods, pressures, or rewards (Ryan and Deci, 2000). White points out that there are many organisms which engage in exploratory, playful, and curiosity-driven behaviours even in the absence of reinforcement or reward (White, 1959; Ryan and Deci, 2000). Ryan and Deci (2000) have further pointed out that a tendency of natural motivation is a critical component in cognitive, social, and physical development due to the fact that it drives inherent interests that individuals grow into knowledge and skills. This means motivation is fundamental in stimulating employees at work, with proper motivation, they are likely to perform poorly, hence affecting services.

\section{The Extrinsic Type of Motivation}

Though intrinsic motivation is inherent, it exists right from childhood, with time, most things are done because of the external factors. In this regard Ryan and Deci (2000) have also pointed out that extrinsic motivation is a construct that pertains whenever an activity is done in order to attain some separable outcome. Deci (1971 and Ryan and Deci (2000) are of the view that after early childhood, freedom to be intrinsically motivated becomes limited mostly by social demands and newly emerging roles which require individuals to take over responsibility for nonintrinsically interesting tasks.

In most cases, if people feel happy, moved positively or in other words, motivated, their acts may lack intention and a sense of personal causation (Ryan and Deci, 2000). In such a situation, it means motivation has accidentally happened, but there is no value attached to the activity just performed (Ryan, 1995: Ryan and Deci). Researchers have noted that this may be true due to the fact that there is no feeling 
of competence to perform a give task (Deci, 1975; Ryan and Deci, 2000) or the results are not believed (Seligman, 1975), since the actor does not believe in himself or herself.

\section{Quality of Service Provision}

Quality of service is a major contributing factor needed in enhancing customer satisfaction. It assists to bring about customer loyalty and also increases revenue for the organization if effectively and efficiently handled. In any service, quality becomes a measuring load which leads to satisfaction.

Just like quality, a service is an activity performed by a worker or employee or an entrepreneur to a customer or client in a company or organisation or on a private term. A service is not physical and has no ownership. It is the nature and quality of a service which can either make a client satisfied or dissatisfied because satisfaction varies from one person to another. Krutz and Clow, 1998) are of the view that service quality observation heavily depends on a contrast between what is expected and what is provided.

Zeithaml, Berry, and Parasuraman(1996) have pointed out that a proper measure and approach to assess and or evaluate a service is by examining whether it meets a customer's expectations or not. If it meets all the customer demands and interest, then it is a good service, but if it does not, then it can be categorized a poor or bad service. There are six different types of services, they include experience, tangibles, reliability, responsiveness, relationships and empathy, finally value sharing and assurance (Milakovich, 1995).

Services have different characteristics compared to other services or goods, the most common of such characteristic being intangibility, inseparability, perishability and variability. (Zeithaml, Berry and Parasuraman, 1996). Just like it might be in goods production, a service goes through a process and it is this process which is the appropriate standard operating procedure (Kasper, Helsdingen, Gabbott, 2006).

\section{RESEARCH METHODS}

In this study we used a survey research design. Amin (2004) defines a survey design as an approach which provides a systematic description about factual and accurate information.

The sample of this consisted of a total of 102 workers from selected districts of the West Java Province, especially from Bandung city. The sample included human resource managers and other staffs. In the process a total of 102 responded answered the questionnaires but with a respondent rate of $70 \%$ was obtained.

Stratified random samples were used on the 102 respondents. The respondents were selected representatives of the bigger population. This method prevents faults in samples and considers almost every major strutam.

Self-administered questionnaire were used to assess judgment, insight and attitudes about the topic of study. The people involved in the answering of these self-administered questionnaires were the management staff, technical staff and clients at the grassroots who receive public services in Bandung city and other selected regions of the West Java Province.

\section{RESULTS AND DISCUSSION}

In the study, the respondents from the selected regions of the West Java Province were local government employees both male and female employees. However, the majority were female consisting of $61.7 \%$ and the male were only $38.2 \%$. It means that most of the employees in Indonesia are mainly male but also with a big number of female, although there was a difference of $23.5 \%$ of the female employees. This shows that West Java Province, especially Bandung takes care of all sex.

Status of Respondents

In this study, respondents were asked to state whether they were married or not and it was established that most of the respondents as much $83.3 \%$ were married and only $10.7 \%$ comprised of the unmarried population. This shows that West Java Province mostly employees married people. Besides, the respondents were also asked to indicate their ages and it was revealed that $38.2 \%$ of the employees were between 40 and 50 , then followed by those in the age bracket of $20-30$ years making $27.4 \%$ and 30 to years were 
JURNAL BISNIS \& MANAJEMEN

ISSN 1412 - 3681

only $25.4 \%$ while 50 and above consisted of only $8.8 \%$ who are said to be almost clocking retirement age. It means that most of the employees are relatively young in age so still highly motivated.

Regarding education, the respondents were asked to provide their education profile and it was established that $18.6 \%$ had certificates, $28.4 \%$ had diplomas, $44.1 \%$ had degrees, and $8.8 \%$ had masters. They had different years of working experience. Matched with their working experience. It was revealed that $37.2 \%$ had worked for more than 6 years, $31.3 \%$ had worked in the local administration for 3 to 4 years. This means many are permanent staff, hence a motivation.

Further the respondents were asked if their wages or salaries influenced their performance towards service delivery and was revealed that three 3\% strongly agreed, while $8.8 \%$ mentioned that the present salary energizes them to work, hence deliver well on their services. However, due to other factors, the majority disagreed.

In this regard, $21 \%$ of the studied samples agreed that they are paid on time and $47 \%$ disagreed with this information. Such establishment helps service providers to provide better services to their clients.

When it comes Employee Fringe Benefits, $45 \%$ of the employees agreed that the local administration provides fringe benefits which are in line with their expectations. This is in line with the vision and mission of Bandung city and the province at large.

\section{Motivation and Service Delivery}

Finally the responding sample was asked to indicate if they are well motivated to serve the public. It was established that $53.9 \%$ strongly agreed, $24.5 \%$ were not clear of what they could answer and $21.5 \%$ strongly disagreed. In this respect, referring to motivation as the most fundamental factor in quality service delivery, it is concluded that management should maintain the practice of motivational training as a tool for better service delivery.

\section{Motivation and Quality Service Delivery: Correlation and Regression}

This study examined the extent to which independent variables motivation practices individually predicted quality service delivering within Bandung city Government administration. It was established that motivation practices are positive, and significantly predict the quality of service delivery in a decentralised Indonesia.

The results also revealed that about $24 \%$ of the unique variances in the quality of services that Local Governments deliver are in most cases accounted for, by a linear combination of both motivation and good communication. The results further revealed that though communication practices and motivation are essential in service delivery, the effect of formal patterns of communication are stronger than informal communication practices indicating that formal communication practices are at a low point.

Consequently, lateral information flow permits units or departments and individuals to work together, and in harmony which is a critical factor to the delivery of quality services to the people. Finally, these results demonstrated that reforming communication practices (formal \& informal) provided opportunities for the Local Government stakeholders particularly staff to execute their tasks with ease and in coordinated manner, which is a key precursor to better service delivery.

\section{CONSLUSION}

In conclusion, this study has revealed that motivation is of positive significance and influences the quality service delivery in a decentralized Indonesia. There are several types of motivation, however the intrinsic an extrinsic factors are fundamental in human motivation. It is therefore important for employers to try to motivate employees, if they are to attain better services. In regard to factors affecting the quality of service delivery, motivation is the most outstanding of all factors.

\section{REFERENCES}

Amaanda, M.N. (2011). The Impact of Employees' Motivation and Empowerment on Delivering Service Quality to Enhance Customer Satisfaction: Case Company X. Degree Programme in Business Management Thesis, March, 2011, Laurea University 
of Applied Sciences, Laurea Leppävaara. See <http://www.theseus.fi/bitstream/ handle/10024/27677/march\%20final\%>.

Amin, M. E. (2004). Foundations of statistical inference for social research. Kampala, Makerere Printery.

Barnet, T and Simmering, M. (cited on 4th August, 2017). MotivationandMotivation Theory.See <http://www.referenceforbusiness.com/ management/Mar-No/Motivation-andMotivation-Theory.html\#ixzz4ovOuql6c>.

Burton, K. (2012). A Study of Motivation: How to Get Your Employees Moving, SPEA Honors Thesis Spring 2012, Indiana University. See <https://spea.indiana.edu/doc/ undergraduate/ugrd_thesis2012_mgmt_ burton.pdf>.

Bussiness dictionary. (4th August, 2017). Decentralization: Definition. See <http:// www.businessdictionary.com/definition/ decentralization.html>.

Cofer, C. N and Appley, M. H. (1964). Motivation: Theory and Research. Wiley, New York.

Deci, E. L. (1971). Effects of externally mediated rewards on intrinsic motivation. Journal of Personality and Social Psychology, 18, 105115.

Deci, E. L. (1975). Intrinsic motivation. New York: Plenum.

Herzberg, F., Mausner, B., \& Snyderman, B. B. (2011). The Motivation to Work. New Brunswick: Transaction Publisher

Hadi, R., Wahyudin, U., Ardiwinata S. J., and Abdu, J. W. (2015). Education and microfinance: an alternative approach to the empowerment of the poor people in Indonesia, Springer Plus (2015) 4:244, DOI 10.1186/s40064-015-0995-6.
Kasper, H., Helsdingen P. V.,and Gabbott, M. (2006). Services Marketing Management: A Strategic Perspective, 2nd Edition. Wiley.

Kurtz D.L. and Clow K.E. (1998), Services marketing, John Wiley \& Sons, New York.

Maslow, H. A. (1954). Motivation Personality. England: Harper \& Row, Publishers, Inc.

Milakovich, E. M. (1995), "Improvingservice quality", StLucie Press, Delray Beach, FL

Ryan M. R and Deci L. E. (2000). Intrinsic and Extrinsic Motivations: Classic Definitions and New Directions, Contemporary Educational Psychology, 25, 54-67 (2000) doi:10.1006/ ceps.1999.1020. See <http://www. idealibrary.com>.

Ryan, R. M. (1995). Psychological needs and the facilitation of integrative processes. Journal of Personality, 63, 397-42.

Sansone, C and Harackiewicz, J. (2000).Intrinsic and Extrinsic Motivation, 1st Edition: The Search for Optimal Motivation and Performance. Academic Press.

Schneider, B., and Alderfer, C. P. (1973). Three studies of measures of need satisfaction in organizations. Administrative Science Quarterly, 18, 489-505.

Seligman, M. (1975). Helplessness: On depression, development, and death . San Francisco: W. $\mathrm{H}$. Freeman.

Steers, R. M., Lyman W. P, and Gregory A. B. (1996) Motivation and Leadership at Work. 6th ed. New York: McGraw-Hill.

Wahba, M. A. , and House, R. J. (1974). Expectancy theory in work and motivation: Some logical and methodological issues. Human Relations, March, 1974.

White, R. W. (1959). Motivation reconsidered. Psychological Review, 66, 297-333. 


\section{JURNAL BISNIS \& MANAJEMEN}

ISSN 1412 - 3681

Wamaungo, A. J. (2011). Community Participation in the Development of Nonformal Education Programmes in Community Learning Centre. Submitted to Sekolah Pascasarjana, Universitas Pendidikan Indonesia, May 5, 2011.
Jurnal Bisnis \& Manajemen, 2017, Vol. XVIII, No. 2, 83-89

Zeithaml, V A., Berry, L.L and Parasuraman A. (1996). The Behavioral Consequences of Service Quality, Journal of Marketing, Vol. 60, No. 2 (Apr., 1996), pp. 31-46.DOI: 10.2307/125192: American Marketing Association 